\title{
Relative susceptibility of mothbean, Vigna aconitifolia varieties to sucking pests
}

\author{
BL Jakhar, PV Tapre \& MH Patel
}

Journal of Agriculture and Ecology

Volume-5 (June, 2018)

ISSN: $2456-9410$

\section{Journal of Agriculture} and Ecology

ISSN: 2456-9410

Volume: 5

Journal of Agriculture and Ecology (2018) 5: 56-60 http://doi.org/10.53911/JAE.2018.5106 


\section{Relative susceptibility of mothbean, Vigna aconitifolia varieties to sucking pests \\ BL Jakhar $\not$, PV Tapre \& MH Patel}

Pulses Research Station, S.D. Agricultural University, Sardarkrushinagar, Gujarat

Corresponding author: BL Jakhar, E-mail: bjakhar@ rediffmail.com

\begin{tabular}{|c|c|}
\hline Article Info & Abstract \\
\hline $\begin{array}{l}\text { Article history } \\
\text { Received: 02 May } 2018 \\
\text { Accepted: } 25 \text { May } 2018 \\
\text { Available online: } 15 \text { June } \\
2018\end{array}$ & $\begin{array}{l}\text { A filed experiment was conducted to screen relative susceptibility of } \\
\text { nine mothbean, Vigna acobitifolis varieties against two major sucking } \\
\text { pests' viz. jassid and whitefly. It was observed that MBS } 803 \text { and } \\
\text { RMO 4-1-6-09 were less susceptible while RMO-225 and CZM-2 }\end{array}$ \\
\hline $\begin{array}{l}\text { Key Words: Mothbean, } \\
\text { sucking pests, Jassid, } \\
\text { whilefly, incidence. }\end{array}$ & $\begin{array}{l}\text { were highly susceptible and remaining cultivars were moderately } \\
\text { susceptible to jassid. Varieties VMB101 and MBS605 were found to } \\
\text { be less susceptible while CZM-2 and RMO 3-5-70 were highly } \\
\text { susceptible and remaining cultivars were moderately susceptible to } \\
\text { while fly. }\end{array}$ \\
\hline
\end{tabular}

Copyright (C2018 Jakhar et al., This is an open access article published under the terms of the Creative Commons Attribution License, which permits unrestricted use, distribution, and reproduction in any medium, provided the original work is properly cited.

Preferred citation: Jakhar BL, Tapre PV \& Patel MH. 2018. Relative susceptibility of mothbean, Vigna aconitifolia varieties to sucking pests. Journal of Agriculture and Ecology, 5: 56-60; http://doi.org/10.53911/JAE.2018.5106.

\section{Introduction}

Mothbean, Vigna acontifolia (Jacg) Marechal is an important pulse crop of dry, semi dry and semi arid region of India and some other countries of Asia. Among Kharif pulses, it has the maximum capacity to resist drought conditions. Plants cover large area on the surface, conserve moisture and also protect the soil from erosion. Mothbean is mainly used as ' $d a l$ ' and some other preparations. Green pods are used as vegetable. It can also be used as green/dry fodder and green manure. The origin place of mothbean is considered to be India. India has the largest area under mothbean in the world. It is also grown in
Pakistan, Sri Lanka, China and United States of America. In India, mothbean have been grown on about $1.11 \mathrm{M}$ ha with $0.31 \mathrm{MT}$ production and $277 \mathrm{~kg} / \mathrm{ha}$ productivity (Anonymous 2018). In India, mothbean is mainly grown in Rajasthan, Gujarat, Maharastra, Jammu \& Kashmir and Punjab. Mothbean belongs to family Leguminosae sub family Papilionaceae. Its tap roots go deeper in soil which can extract moisture from lower horizons in the soil. Stem is branched with plant height of about $30-35 \mathrm{~cm}$. Leaves are trifoliate. Leaflets are lobed and divided in 3-5 parts. Flowers are papilionacious and mostly self pollinated. Pods are 2.5 to $5.0 \mathrm{~cm}$ long 
containing 5-9 seeds. Seeds are yellowish in colour, germination is epigeal.

Jassid, whitefly, thrips, black weevil, pulse beetle and white grubs are considered as major pests while termites, galerucid beetle, mites and surface grass hoppers are of minor nature (Pareek et al. 1983; Jakhar et. al. 2016). Among them jassids, whiteflies and thrips are major sucking pest cause moderate to severe damage starting right from germination to maturity of the crop and leads to considerable yield loss (Puttaswami et al. 1977; Jakhar et al. 2017).

\section{Materials and Methods}

The field experiment was conducted at Pulses Research Station, S. D. Agricultural University, Sardarkrushinagar during kharif, 2017. The seeds of nine cultivars were sown at $45 \times 10 \mathrm{~cm}$ spacing in $3.0 \times 2.7 \mathrm{~m}$ size plots under randomized block design with three replication. The populations of sucking pests were recorded at weekly intervals right from germination to harvesting of crop. The pest populations were recorded on five randomly selected tagged plants in morning hours (Before 8 AM), when insects had minimum activity (Haldhar et al. 2017). The methods used for recording the population of major sucking pests have been described below:

Jassid: The jassid population was recorded by counting both nymphs and adults, on randomly selected and tagged whole plants in the initial stage of crop and on six leaves per plant, two each from top, middle and bottom in later stages.

Whitefly: For estimating the whitefly population, the observations were recorded on whole plant in the initial stage and on six leaves from upper, middle and lower portion of randomly selected and tagged plants, in the later stage. The population was counted by holding the base of leaves gently until the entire underside of leaf was clearly visible. Population was estimated with least disturbance at early hours of the day. The peak population of these pests on mothbean varieties/genotypes recorded during the crop season was categorized on the basis of following formula.

Where,

$\overline{\mathrm{X}}=$ Mean of the peak population.

$\sigma=$ Standard deviation for insect population.

So as categorized were made as

1. Less susceptible

2. Moderately susceptible

3. Highly susceptible

\section{Results and Discussion}

It is well known that certain varieties of crops are attacked lesser by insects than others because of natural resistance. To minimize the losses caused by insect-pests, growing of resistance varieties is one of the most important tools currently employed in the insect pest management without additional cost. During the present investigations, nine varieties/genotypes of mothbean were screened for their relative susceptibility to major sucking pests during Kharif, 2017 in arid region of Gujarat. Two sucking pests namely, Jassid (Empoasca carri) Whitefly, (Bemisia tabaci) were observed infesting mothbean varieties/genotypes namely CZM-2, RMO257, RMO-3-5-70, RMO-225, RMO435, MBS605, RMO 4-1-6-09, VMB102, VBM101 and MBS 803. 
Jassid: The mean population of jassid was varied from 0.80 to 1.67 jassids/ leaf on different varieties/genotypes throughout the crop season. The population of Jassis was found significantly less in MBS 803 which was at par with RMO 4-1-6-09 and MBS 605. The maximum population was recorded on RMO-225 followed by CZM-2 and all these genotypes were at par.

On the basis of population, susceptibility of mothbean varieties/ genotypes to jassid was determined. The mothbean varieties/genotypes were categorized on the basis of overall mean jassid population, using the following formula $\bar{X} \pm \sigma$ . Accordingly, the varieties/genotypes having population less than 0.85 jassid per plant were rated as less susceptible, the varieties having population 0.86 to 1.51 jassids per plant rated as moderately susceptible, and the varieties having more than 1.52 jassids per plant rated as highly susceptible to jassids. Considering this formula the two varieties viz., MBS 803 and RMO-4-1-6-09 was rated as less susceptible; Five varieties namely MBS605,VMB101,RMO3-5-70, VMB102 and RMO-257 were rated as moderately susceptible and two varieties namely CZM-2 and RMO-225 was found susceptible to jassid.

The results were in full conformity with study conducted at ARS, Bikaner where RMO-4-1-6-09 was found least susceptible to jassid (Anonymous, 2018).

In the present investigations, varieties MBS605, VMB101, RMO 3-5-70, VMB102 and RMO-257 were observed as moderately susceptible. The present findings get support from the findings of Naga (2012) who categorized RMO-40 and RMO-257 as moderately susceptible to jassid infestation. The results were in full conformity with study conducted at ARS, Bikaner where RMO 3-570 and RMO-257 was found least susceptible to jassid (Anonymous, 2018).

In the present investigation, varieties CZM-2 and RMO-225 were found highly susceptible to jassid. The results were in full conformity with the results of Bairwa (2005) who reported RMO-225 was highly susceptible to jassid.

Whitefly: The mean population of whitefly varied from 0.73 to 1.27 per leaf on different varieties/genotypes throughout the crop season. The mothbean varieties/genotypes were categorized on the basis of overall mean whitefly population, using the following formula $\bar{X} \pm \sigma$. According to this formula nine varieties/genotypes were categorized as less susceptible, moderately susceptible and highly susceptible. The varieties/ genotypes VMB101 and MBS605 having population less than 0.78 whitefly per leaf were rated as less susceptible while varieties/genotypes viz., MBS 803, RMO-4-1-6-09, RMO-257, VMB102 and RMO-225 ranging population between 0.79 to 1.18 whitefly per leaf rated as moderately susceptible, varieties/genotypes: CZM-2 and RMO 3-5-70 with the population above 1.19 whitefly per leaf rated as highly susceptible to whitefly. 
Table 1. Pest incidence on different verities/cultivars of mothbean

\begin{tabular}{clcc} 
Sr. No. & Genotypes & Leaf hopper/leaf & Whitefly/leaf \\
\hline 1 & CZM 2C & $1.61(1.60)$ & $1.49(1.23)$ \\
2 & RMO 257@ & $1.54(1.37)$ & $1.38(0.90)$ \\
3 & RMO 3-5-70 & $1.49(1.23)$ & $1.50(1.27)$ \\
4 & RMO225 C & $1.63(1.67)$ & $1.46(1.13)$ \\
5 & MBS605 & $1.37(0.87)$ & $1.33(0.77)$ \\
6 & RMO 4-1-6-09 & $1.35(0.83)$ & $1.38(0.90)$ \\
7 & VMB102 & $1.50(1.27)$ & $1.44(1.07)$ \\
8 & VBM101 & $1.43(1.03)$ & $1.31(0.73)$ \\
9 & MBS 803 & $1.34(0.80)$ & $1.37(0.87)$ \\
& S.Em \pm & 0.016 & 0.017 \\
& CD at 5\% & 0.049 & 0.051 \\
& CV \% & 6.91 & 5.07
\end{tabular}

$* \sqrt{X}+0.5$ transform values Figures in parenthesis are retransformed values

Table 2. Categorization of varieties/genotypes on the basis of mean population of leaf hopper

$\begin{array}{cccc}\text { S. } & \text { Population } & \text { Rating } & \begin{array}{c}\text { No. of } \\ \text { varieties/ } \\ \text { genotypes }\end{array}\end{array}$

\begin{tabular}{cclcc}
\hline 1 & Below $<0.85$ & $\begin{array}{l}\text { Less } \\
\text { susceptible }\end{array}$ & 2 & MBS 803, RMO-4-1-6-09 \\
2 & $0.86-1.51$ & $\begin{array}{l}\text { Moderately } \\
\text { susceptible }\end{array}$ & 5 & $\begin{array}{c}\text { MBS605,VMB101,RMO3-5-70, } \\
\text { VMB102,RMO-257 }\end{array}$ \\
3 & Above 1.52 & $\begin{array}{l}\text { Highly } \\
\text { susceptible }\end{array}$ & 2 & CZM-2,RMO-225 \\
\hline
\end{tabular}

Mean -1.18 , SD-0.33 Cut off value= Mean-S.D $=0.85$

Table 3. Categorization of varieties/genotypes on the basis of mean population of whitefly

\begin{tabular}{cclcc}
\hline S. No. & $\begin{array}{c}\text { Population/ } \\
\text { plant }\end{array}$ & Rating & $\begin{array}{c}\text { No. of } \\
\text { varieties/genoty } \\
\text { pes }\end{array}$ & Name of varieties/genotypes \\
\hline 1 & Below<0.78 & $\begin{array}{l}\text { Less } \\
\text { susceptible } \\
\text { Moderately }\end{array}$ & 2 & VMB101, MBS605 \\
3 & $0.79-1.18$ & $\begin{array}{l}\text { susceptible } \\
\text { Highly } \\
\text { susceptible }\end{array}$ & 5 & $\begin{array}{c}\text { MBS 803, RMO-4-1-6-09,RMO- } \\
\text { 257, VMB102,RMO-225 } \\
\text { CZM-2,RMO 3-5-70 }\end{array}$ \\
\hline
\end{tabular}

Mean -0.98, SD-0.20 Cut off value $=$ Mean-S.D $=0.78$ 
In the present findings, the varieties/genotypes VMB101 and MBS605 were observed as less susceptible to whitefly infestation. The results were in full conformity to the study conducted at ARS, Bikaner where genotype VMB101 was found least susceptible to whitefly (Anonymous 2018). In the present investigation, varieties/genotypes viz., MBS 803, RMO-4-1-6-09, RMO-257, VMB102 and RMO-225 were observed as moderately susceptible. Simillar results The present findings get support from the findings of Naga (2012) who reported RMO-257 as moderately susceptible. The results were in full conformity to the study conducted at ARS, Bikaner where genotype RMO-4-1-609, RMO-257 and RMO-225 were found least susceptible to whitefly (Anonymous 2018).

In the present investigations, variety CZM-2 and RMO 3-5-70 was found highly susceptible to whitefly. The work on these genotypes screened in the present investigation has not been traced in the literature; therefore, the performance of these varieties could not be compared and discussed.

\section{References}

Anonymous 2013. Annual Report. National Network Research Project on Arid Legumes, pp. 251-252.Central Arid Zone Research Institute, Jodhpur (Rajasthan).

Anonymous 2018 . Annual Report. National Network Research Project on Arid Legumes, pp. 2-3.Indian institute of Pulses Research, Kanpur (U.P.).

Bairwa DK. 2005. Management of major insect-pests of mothbean, Vigna aconitifolia (Jacq.) Marechal, Ph.D. thesis submitted to Rajasthan Agricultural University, Bikaner.

Haldhar SM, Samadia DK, Bhargava R \& Singh D. 2017. Host plant genotypes determine bottom-up effect of Cucumis melo var. callosus against melon fruit fly. Crop Protection, 98: 157-165.

Jakhar BL, Singh N, Tapre PV, avindrababu Y \& Venilla S. 2017. Study the influence of climate change on Clavigralla gibbosa (Spinola) in pigeonpea. Journal of Agriculture and Ecology, 4: 37-43.

Jakhar BL, Singh N, Venilla S, Patel MH, Vekaria MV, Patel DB \& Panicar B. 2016. Influence of climate change on Helicoverpa armigera (Hubner) in pigeonpea. Journal of Agriculture and Ecology, 2: 25-31.

Naga KL. 2012. Varietal screening and management of major sucking pests of mothbean, Vigna aconitifolia (Jacq.) Marechal in hyper arid region of Rajasthan. M. Sc. (Ag.) Thesis . Swami Keshwanand Rajasthan Agriculture University, Bikaner.

Pareek BL, Sharma RC \& Yadav CPS. 1983. Records of insect faunal complex on mothbean, Vigna aconitifolia (Jacq.) Marechal in semi-arid zone of Rajasthan. Bulletin of Entomology, 24 (1): 44-45.

Puttaswami, Gowda BLV \& Ali TMM. 1977. Record of pests infesting mothbean, Phaseolus aconitifolia (Jacq.) a potential pulse crop. Current Research, 6 (4): 6971. 